Volume 2 Issue 1, June 2021, 16-24

Available online at:

https://ejournal.upi.edu/index.php/JAFN

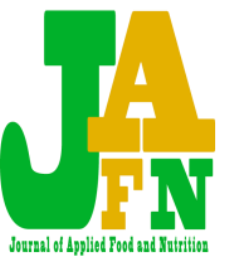

\title{
The Effect Of Moringa Leaf (Moringa Oleifera L.) Powder Substitution In Physicochemical And Organoleptic Characteristics Of Ice Cream
}

\author{
Rima Anjani, Akhmad Zakaria, Windy Widowaty* \\ Universitas Al-Ghifari. Cisaranten Kulon No. 140 Street, Bandung 40293, West Java, \\ Indonesia \\ *Corresponding Author. E-mail: windy.widowaty@unfari.ac.id
}

\begin{abstract}
A B S T R A C T S
Protein and calcium are two nutrients that are essential to the human body. These nutrients can be acquired through the consumption of animal and vegetable foods. Moringa leaves are a protein and calcium-rich vegetable dietary product. The goal of this study is to investigate the physicochemical and organoleptic properties of ice cream products by the addition of Moringa leaf powder. This study used an experimental method with a one-factor total randomized design. The addition of $0 \%, 3 \%, 6 \%, 9 \%$, and $12 \%$ Moringa leaf powder treatment was carried out with 5 repetitions. The Kjeldahl method was used to analyse total protein content and Atomic Absorption Spectrophotometry was used to analyse the amount of Calcium in ice cream products. In this research, we tested the volume, mass, overrun, and melting time of ice cream, and so do the hedonic, and organoleptic characteristics. The results showed that calcium and protein levels of Moringa ice cream increased along with the addition of Moringa leaf powder. Ice cream with the addition of Moringa leaf powder by $12 \%$ had an average value of calcium and protein content higher compared to other ice cream samples. The addition of $9 \%$ Moringa leaf powder gave the bestoverrun value of $47.86 \%$ which was determined based on the swelling power of the ice cream dough. Ice cream with 3\% Moringa powder has the longest melting power of 12.82 minutes. organoleptic test results show that ice cream with 3\% Moringa has the highest level of preference, with a total point of 527 for colour, 509 for aroma, 559 for taste, and 546 for texture. This study shows that Moringa leaves can be used as a substituent in ice cream.
\end{abstract}

\begin{tabular}{l}
\hline \multicolumn{1}{c}{ A R T I C L E I N F O } \\
\hline Article History: \\
Received April 2021 \\
Revised May 2021 \\
Accepted June 2021 \\
Available online June 2021 \\
Keywords: \\
Ice cream; Moringa leaf; \\
Protein; Calcium; Melting \\
Power; Overrun; \\
Organoleptic.
\end{tabular}

\author{
Keywords: \\ Ice cream; Moringa leaf; \\ Protein; Calcium; Melting \\ Power;
Organoleptic.
}




\section{Introduction}

Ice cream has a foam structure, which is a gas dispersed in a liquid that may be preserved by keeping it cooled or frozen. Ice cream has a physical appearance as solid, but microscopically it consists of solid milk fat globules, air $(<0.1 \mathrm{~mm})$, ice crystals, and water that dissolves sugar, salt, and milk protein (Ismunandar, 2004). The ingredients used in making ice cream are fat, skimmed milk solids, granulated sugar, stabilizers, emulsifiers, and flavors (Kalsum, 2012). The fat in milk contributes to the ice cream's smoothness, while skim milk helps the emulsification process. Sugar act to give a sweet taste to the ice cream product and a stabilizer is used in the production of ice cream to avoid the development of coarse ice crystals. (Nuraini, 2007).

Ice cream contains calcium, phosphor, protein, vitamins, fats, and minerals. The calcium content in ice cream helps to preserve bone mass density, prevent osteoporosis, cancer, and hypertension. Protein is an essential nutrient that acquired by the body for muscular tissue repair and metabolism process. Milk is the main component in ice cream, which provides a variety of vitamins such as vitamins $\mathrm{A}, \mathrm{D}, \mathrm{E}, \mathrm{K}$, and B12. However, most of the nutrients in ice cream are easily degraded when they are processed (Rohmanah, 2013). In this study, we are trying to improve the nutrition quality of ice cream by adding substituents that can prevent nutrition deterioration during ice cream production. Moringa leaves contain a nutritional profile that is comparable to that of cow's milk. The addition of Moringa leaf powder into ice cream is expected to compensate for the nutritional value lost during the ice cream manufacturing process (Wijayanti, 2016).

Several studies have studied the effect of these Moringa leaf powder as milk substituted for various products, such as; The Effect of Addition of Moringa Leaf Powder (Moringa oleifera) to the Organoleptic and Chemical Characteristics of MOCAF Biscuits (Modified Cassava Flour) the moisture content of Moringa powder was $9.57 \%$ and protein content of $26.02 \%$ (Augustyn et al, 2017). Meanwhile, according to research by Panjaitan (2013) in the book of Moringa Mineral Block Supplements, the calcium content of Moringa powder is 2.003\%. Physical measurements of Moringa ice cream, that the higher the concentration of Moringa powder added, the higher the nutritional content of ice cream (Kurnianingasih, 2015).

The objective of this study is to identify the effect of Moringa leaf powder on the calcium and protein content in ice cream. In addition, this study also analyses the psychochemical and organoleptic characteristics of ice cream products made with the addition of Moringa leaf powder. The findings from this study can theoretically be considered as a source of information for researchers, as well as a reference for relevant future research.

\section{Materials and Methods}

This research was done in the Laboratory of Food Processing and Laboratory of Instrumentation Analysis, Al-Ghifari University, Bandung, West Java Province. This study used an experimental method with a one-factor completely randomized design. Analysis of psychochemical and organoleptic was conducted towards ice cream sample with additions of $3 \%, 6 \%, 9 \%, 12 \%$ of Moringa leaves powder. There are several stages in this research, namely preparation of Moringa leaves powder, production of Moringa ice cream, psychochemical analysis, organoleptic analysis, and hedonic testing.

\subsection{Preparation of Moringa leaves powder}

Moringa powder is made from fresh Moringa leaves that have gone through the process of sorting, washing, drying, crushing, and sifting. The tools used in the process of making 
Moringa leaf powder are a dry blender, food dehydrator, sieve (100 mesh), stopwatch, a digital scale, and airtight container. Moringa powder was made using a food dehydrator (Zakaria, 2016). The process begins with the sortation of Moringa leaves. In this study, only whole green leaves from the second to seventh stalks were used to make Moringa powder. After sortation, the leaves were washed using flowing water and continued by drying them using a food dehydrator at $60^{\circ} \mathrm{C}$ for 120 minutes. Dried Moringa leaves were then crushed using a dry blender and then sieved with a 100 mesh sieve to separate small stems. Moringa powder was stored in an airtight plastic container for further analysis.

\subsection{Production of Moringa ice cream}

Production of Moringa ice cream was carried out by following methods by Ramadhani (2020), with some modification. The ice cream was made using skim milk powder, full cream milk, granulated sugar, cornstarch, egg yolks, and Moringa leaf powder. The tools used in making Moringa ice cream are ball whisk, ice cream maker, pan, spatula, stopwatch, thermometer, digital scale, and a closed container. The ice cream is made by mixing full cream milk with other dry ingredients such as sugar, powdered milk, and cornstarch. The mixture was stirred until homogenous and then pasteurized at $80^{\circ} \mathrm{C}$ for 5 minutes. subsequently, the dough was mixed with egg yolk and then cooled at room temperature for 10 minutes and continued with a freezing process for about 3-5 hours. The frozen dough was put into the ice cream maker and added with Moringa leaf powder with a concentration of $0 \%, 3 \%, 6 \%, 9 \%$, and $12 \%(\mathrm{w} / \mathrm{w})$, followed by agitation for 25 minutes. The process continued by keeping the ice cream in a freezer at $18^{\circ} \mathrm{C}$ for $8-10$ hours.

\subsection{Psychochemical analysis}

The ice cream was analyzed for protein and calcium content. The Kjeldahl method was used to analyze total protein, and Atomic Absorption Spectrophotometer (AAS) method was used to measure the amount of calcium. The procedure was carried out using chemicals with pro analysis grade, namely aquadest, $\mathrm{K}_{2} \mathrm{SO}_{4}, \mathrm{HNO}_{3}$, anhydrous sulfur acid, $\mathrm{HCl} 0.1 \mathrm{~N}_{2} \mathrm{H}_{2} \mathrm{SO}_{4}$, methyl red indicator, $\mathrm{CuSO}_{4}, \mathrm{NaOH} 30 \%$, and $\mathrm{NaOH} 0.1 \mathrm{~N}$. Equipments used in the Kjeldahl method are analytical balance, Kjeldahl flask, complete distillation apparatus, complete titration apparatus, a burner, Erlenmeyer, pipette, volume pipette, Wathman No.42 filter paper, stirring rod, volumetric flask, stopwatch, litmus paper, spectrophotometer, and measuring cup.

The physical aspect was determined by calculating the overrun percentage and melting point of the ice cream. The overrun percentage was measured by weighing the mass of the dough in a container with a volume of $100 \mathrm{~mL}$ before and after the freezing process. Melting point measurement is done by calculating the time it takes for the ice cream to melt completely at room temperature.

\subsection{Organoleptic testing}

The ice cream samples were also tested for their organoleptic and hedonic aspects. The tools used in the organoleptic analysis are small trays, plastic cups, plastic spoons, and questionnaires. The organoleptic response carried out was acceptance testing using a hedonic test, in which the panelists conveyed the results of liking or disliking a modified product. The criteria tested include aroma, taste, color, and texture. The test was conducted by 20 untrained panelists. Each panelist will be given a questionnaire sheet and asked to convey the impression they achieved through a hedonic scale, namely very much like, very like, like, dislike, very dislike, very much dislike. 


\section{Results and Discussion}

\subsection{Calcium Content of Moringa Ice Cream}

Analysis of calcium content in ice cream was carried out using Atomic Absorption Spectroscopy. With its simplicity, precision, and speed, atomic absorption spectroscopy (AAS) is recommended for determination of elements in a sample. The results from the analysis of calcium revealed that the addition of $12 \%$ moringa powder showed the highest calcium content of $45.729 \mathrm{ppm}$; meanwhile, ice cream without any addition of moringa powder only had 28.267 ppm of calcium (Figure 1.). Data analysis showed that the calcium content in ice cream increases along with the addition of moringa powder in ice cream. A study in 2019, analyze the calcium content of ice cream enriched with Bacopa monniera. The results showed that calcium level in enriched ice cream was $165 \mathrm{mg} / 100 \mathrm{~g}$, compared to $145 \mathrm{mg} / 100 \mathrm{~g}$ in control ice cream (Baig et al., 2019).

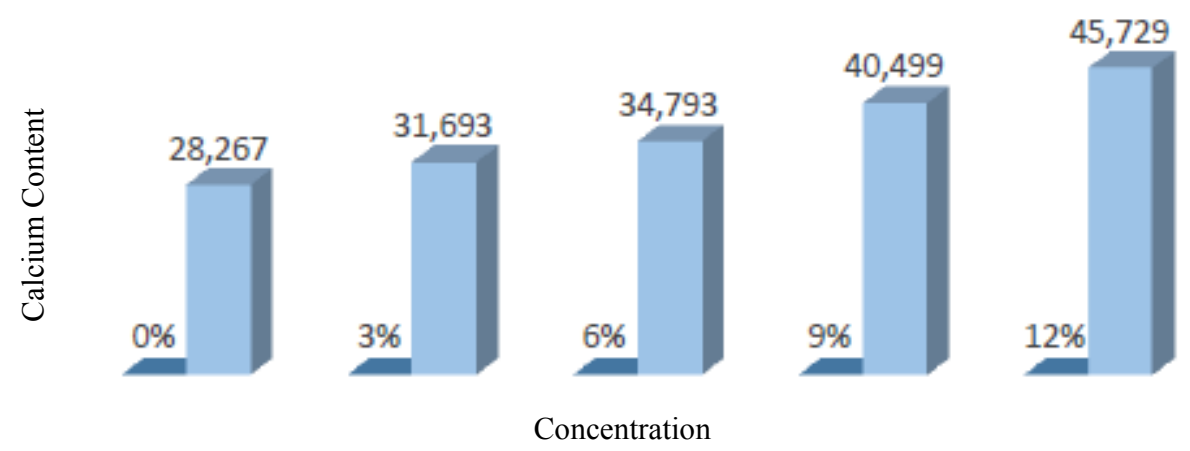

Figure 1. Calcium Content of Ice Cream with Various Addition of Moringa Leaf Powder

The Kjeldahl method was used to determine the ice cream's crude protein content as defined in AOAC (AOAC and Helrich, 1990). Addition of Moringa leaf powder showed that the highest protein value was obtained from the addition of $12 \%$ Moringa leaf powder with an average value of $11.258 \%$; meanwhile, ice cream without any addition of moringa showed a value of $5.6228 \%$. From these results, it can be concluded that the addition of Moringa leaf powder affects the protein value. With the more addition of Moringa leaf powder, the protein value will increase (Figure 2). A study in 2021 revealed that the addition of spices in ice cream does significantly increase the protein content in ice cream. Spicy coconut ice cream has a higher protein content than the recommended ice cream protein content (4\%) (Perera and Perera, 2021). 


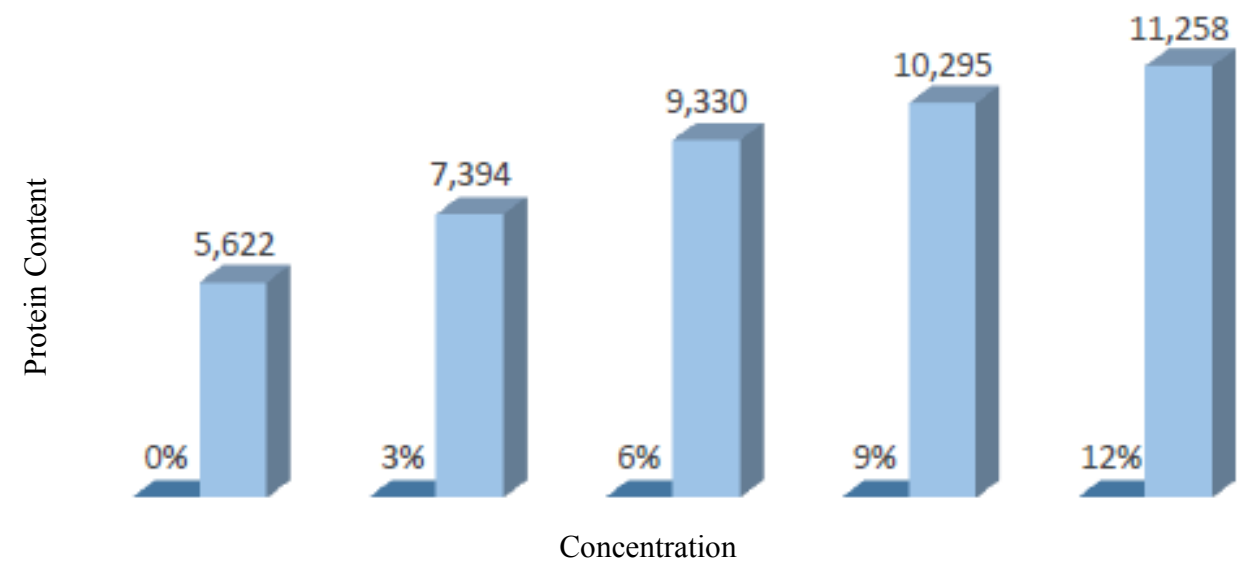

Figure 2. Protein Content of Ice Cream with Various addition of Moringa Leaf Powder

Melting power is the time it takes for ice cream to melt completely at room temperature once it has been frozen. The melting power of ice cream with the addition of moringa is presented in Figure 3. The addition of Moringa leaf powder showed that the highest melting power was obtained from the addition of 3\% Moringa leaf powder with an average value of 12.816 and the lowest value was obtained from the addition of $13 \%$ Moringa leaf powder with an average value of 10.048. According to SNI No. 01-3713-1995, 15-25 minutes is a good melting range for ice cream. The melting power of the ice cream also affects its quality. Consumers would prefer an ice cream that does not melt easily at room temperature $\left(27^{\circ} \mathrm{C}\right)$. In This study, all the ice cream has a lower melting power compared to the standard of SNI, thus the procedure in the ice cream making should be evaluated. Addition of solid component to the ice cream mixture should increase the melting power, since in a lower density ice cream would be easier to melt (Hapdang et al., 2021).

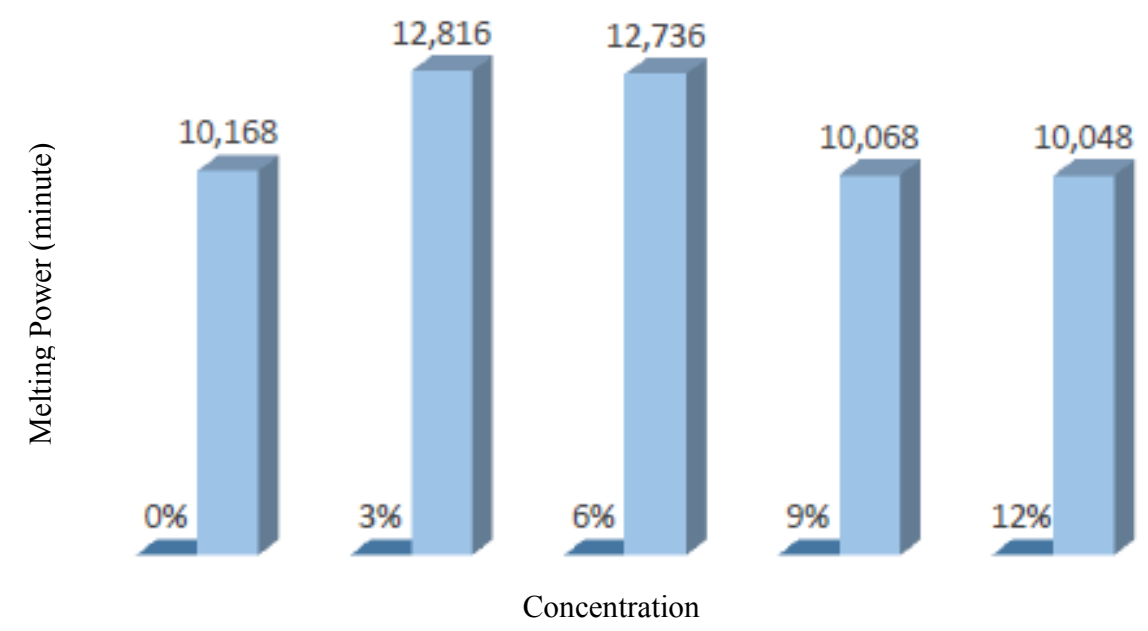

Figure 3. Melting Power of Ice Cream with Various addition of Moringa Leaf Powder 
The ingredients used to make ice cream affect the properties of the ice cream. The number of ingredients used determines the total solids in the ice cream. The low total solids cause the amount of frozen water to increase so that the air trapped in the ice cream is less and the expansion of the ice cream will be limited, resulting in a low overrun of ice cream (Arbuckle, 1986). The raw materials used in the process of making ice cream include fatty milk, fat-free milk, sweeteners, emulsifiers, and stabilizers.

The role of air in ice cream lies in overrun. Overrun is one of the most important qualities of ice cream products (BSN, 1995). Overrun is the expansion of volume, namely the increase in volume between before and after the freezing process (Hubeis, 1995). Overrun is a parameter to determine the increase in the volume of ice cream due to the trapped air in the ice cream dough due to the agitation process (Oxilia et al, 2012). The higher the overrun value, the better quality that the ice cream have. The overrun of ice cream is usually between $70-80 \%$ for the manufacturing industry and for the home industry scale is around 35-50\% (Suprayitno et al, 2001).

The overrun value is directly proportional to the melting power, the higher the overrun value the ice cream produced will melt faster (Suprayitno et al, 2001). Melting power is the time it takes for ice cream to melt completely in room temperature. High-quality ice cream does not melt quickly when served at room temperature. The melting power of ice cream can be affected by ice cream raw materials such as protein, solids, and stabilizers. In addition, the manufacturing process such as homogenization can affect the speed of melting ice cream. Improper homogenization causes the distribution of fat and air to be less evenly distributed, resulting in a rough texture and increased overrun. The high overrun causes the ice cream to melt quickly at room temperature (Padaga and Sawitri, 2005).

The treatment with the addition of Moringa leaf powder showed that the highest overrun was obtained from the addition of Moringa leaf powder as much as $12 \%$ with an average value of 47.857 and the lowest value was obtained from the ice cream without any addition of Moringa leaf powder with an average value of $45.682 \%$. From these results, it can be concluded that the addition of Moringa leaf powder affects overrun. The more addition of Moringa leaf powder, the higher the overrun (Figure 4).

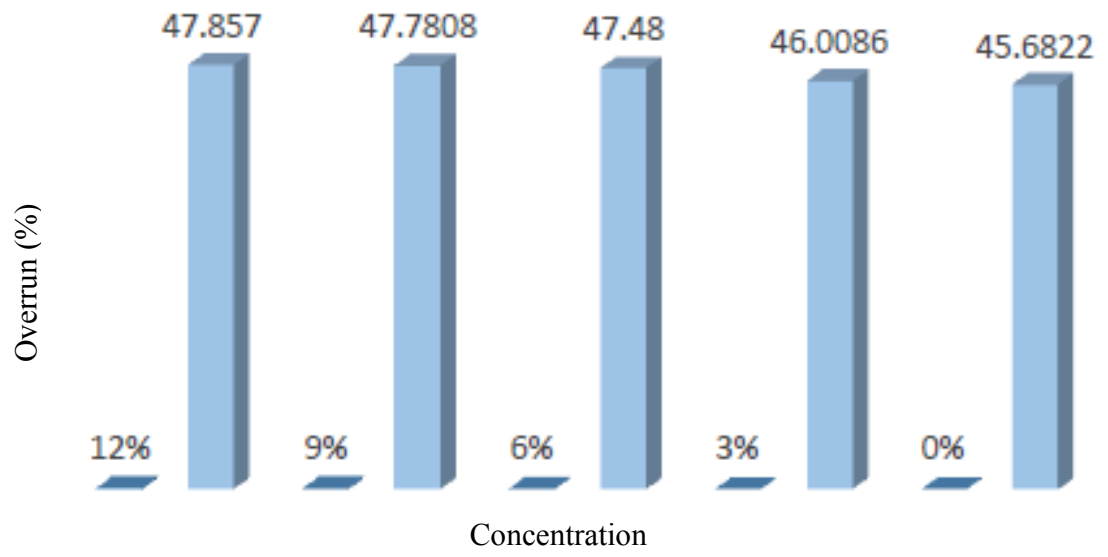

Figure 4. Ice Cream Overrun with Various addition of Moringa Leaf Powder

Data obtained from sensory evaluation revealed that sample 402, containing 3\% moringa leaf powder is the most acceptable formula, with an average value of 559. The color, aroma, 
flavor, and texture of sample 402 were higher compared to any other samples. Meanwhile, sample 204, containing $12 \%$ moringa leaf powder were sample with the most unacceptable formula, with an average value of 268 (Figure 5.). A study in 2019, revealed that utilization of $25 \mathrm{~g}$ moringa in ice cream product was recommended, since it was acceptable by the panelist and has appropriate the quality standards of ice cream (Iskandar et al., 2019).

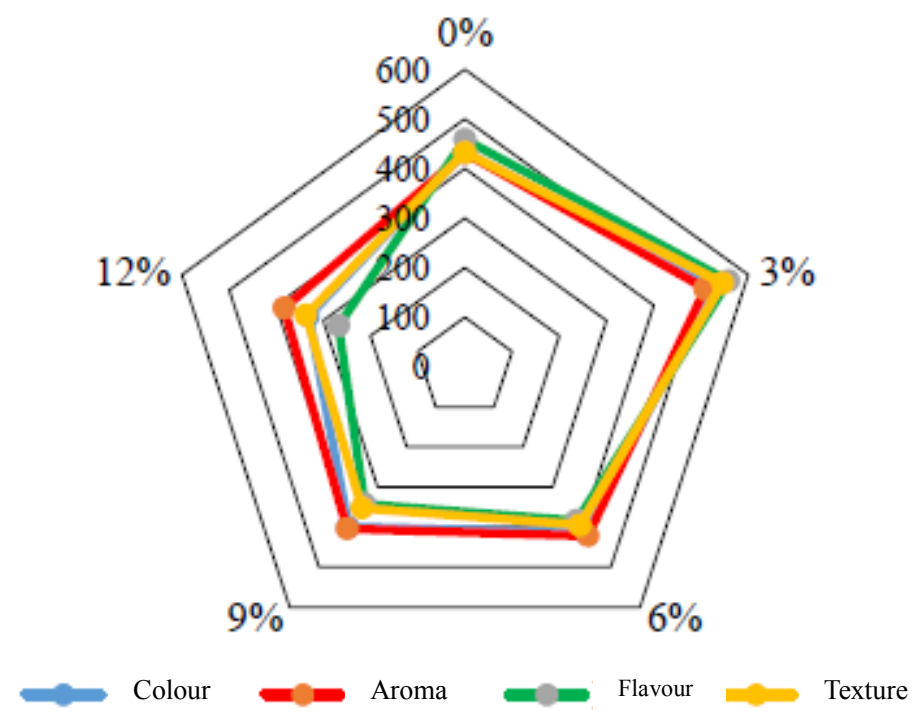

Figure 5. Hedonic Test of Ice Cream with Various addition of Moringa Leaf Powder

Currently, the ice cream industry in the world is growing rapidly so that the variety and presentation are increasingly diverse. Many ice cream industries combine ice cream with chocolate syrup, fresh fruits, yogurt, and nuts either mixed or just sprinkled on top (Chan, 2008). To find out the public's acceptance of innovative products, organoleptic testing is usually held. Organoleptic testing (acceptance) is a test using the human senses as the main tool for measuring product acceptance. Acceptance testing is an important role in the application of the quality of a product. Acceptance testing can provide an indication of quality deterioration and other defects of a product produced/manufactured. Sensory analysis is important in food products, if the taste is not good then the nutritional value cannot be utilized because no one consumes it (Setyaningsih et al, 2012).

\section{Conclusions}

Calcium and protein content in ice cream has increased along with the addition of Moringa leaf powder. Ice cream with the addition of $12 \%$ Moringa leaf powder has the highest calcium and protein content compared to other ice creams. The addition of $12 \%$ Moringa leaf powder gave the best-overrun value of $47.857 \%$ which was determined based on the swelling power of the ice cream dough. The results also revealed that the addition of 3\% Moringa leaf powder resulted in ice cream that has the longest melting power of 12,8160 minutes.

The addition of Moringa leaf powder of $0 \%, 3 \%, 6 \%, 9 \%$, and $12 \%$ gave a significantly different effect on the organoleptic of ice cream which included testing of color, aroma, taste, and texture. Ice cream with $3 \%$ moringa leaf powder is the most acceptable formula, with an average value of 559. Meanwhile, ice cream with $12 \%$ moringa leaf powder were sample with the most unacceptable formula, with an average value of 268. 


\section{References}

Iskandar, A., Ningtyias, F., \& Rohmawati, N. (2019). The Analysis of Protein and Calcium Levels as well as the Acceptability of Ice Cream by Adding the Flour of Moringa Oleifera Leaves. Penelitian Gizi Dan Makanan: The Journal of Nutrition and Food Research, 42(2), 65-72. https://doi.org/10.22435/pgm.v42i2.3872

A Hapdang et al 2021 IOP Conf. Ser.: Earth Environ. Sci. 788012105

K. D. S. S. Perera, O. D. A. N. Perera, "Development of Coconut Milk-Based Spicy Ice Cream as a Nondairy Alternative with Desired Physicochemical and Sensory Attributes", International Journal of Food Science, vol. 2021, Article ID 6661193, 7 pages, 2021. https://doi.org/10.1155/2021/6661193

Association of Official Analytical Chemists (AOAC), and Helrich, K, Official Methods of Analysis of the Association of Official Analytical Chemists, The Association, Arlington, VA, 15th edition, 1990.

Baig, M. D. ; Kumar, M. D. ; Beena, A. K. ; Rajakumar, S. N. ; Gopalakrishnan, K. A. 2019. Qualitative and quantitative examination of bacosides and calcium in calcium enriched herbal ice cream by HPLC and AAS.Indian Journal of Dairy Science. Vol.72 No.1 47-52.

Almatsier, S. 2009. Prinsip Dasar Ilmu Gizi. Jakarta : PT. Gramedia Pustaka Utama.

Alvionikita, I. B. 2018. Analisis Kadar Protein, Kalsium Dan Daya Terima Es Krim Dengan Penambahan Tepung Daun Kelor (Moringa oleifera L.). Skripsi. Jember : Fakultas Kesehatan Masyarakat Universitas Jember.

Amaglo N.K., Timpo G.M., Ellis W.O., and Bennett R.N. 2006. Effect of spacing and harvest frequency on the growth and leaf yield of Moringa (Moringa oleifera Lam.), a leafy vegetable crop. Moringa and other highly nutritious plant resources: Strategics, standards, and markets for a better impact on nutrition in Africa. International workshop on Moringa; Accra, 16-18 November 2006.

Aminah, S., Ramdhan, T. dan Yanis, M. 2015. Kandungan Nutrisi dan Sifat Fungsional Tanaman Kelor (Moringa oleifera L.). Buletin Pertanian Perkotaan. 5(2):35-44.

Andreasen, T.G., dan Nielsen. 1998. Ice Cream and Aerated Dessert. The Technology of Dairy Products Blackie Academic and Professional. London Weinheim-New York-TokyoMelbourne-Madrid.

Arbuckle, W. S. 1986. Ice Cream. The AVI Publishing Company, INC. Westporn Connecticut, London.

Augustyn, G.H., Tuhhumury, H.C.D., Dahoklory, M. 2017. Pengaruh Penambahan Tepung Daun Kelor (Moringa oleifera) Terhadap Karakteristik Organoleptik Dan Kimia Biskuit MOCAF (Modified Cassava Flour). Jurnal Teknologi Pertanian. AGRITEKNO. Vol. $6(2): 52-58$.

Badan Standarisasi Nasional. 1995. Standar Nasional Indonesia 01-2981-1995. Es Krim . Jakarta : Dewan Standar Indonesia.

Badan Standarisasi Nasional. 2008. Standar Nasional Indonesia 0936-2008. Viskositas . Jakarta : Dewan Standar Indonesia. Badan Standarisasi Nasional. 2015. Standar Nasional Indonesia 2970-2015. Susu Bubuk . Jakarta : Dewan Standar Indonesia.

Broin, M. 2010. Growing and Processing Moringa Leaves. Moringanews. Ghana: Moringa Association of Ghana.

Chan, I., A. 2008. Membuat Es Krim. Jakarta : Agromedia Pustaka.

Darwin, Phillips. 2013. Menikmati Gula Tanpa Rasa Takut. Perpustakaan Nasional : Sinar Ilmu.

Direktorat Gizi Departemen Kesehatan Republik Indonesia. 2005. Daftar Komposisi Bahan Makanan. Jakarta : Depkes RI. 
Direktorat Gizi Departemen Kesehatan Republik Indonesia. 1981. Daftar Komposisi Bahan Makanan. Jakarta : Bhratara Karya Aksara.

Doerr B., Cameron L. 2005. Moringa Leaf Powder. ECHO Technical Note. USA.

Fennema, R.O. 2008. Food Chemistry. Revised and Expanded Academi Pres. New York.

Gazpersz, Vincent. 1995. Teknik Analisis Dalam Penelitian Percobaan. Bandung : Tarsito.

Hadiwiyoto, S. 1983. Hasil-Hasil Olahan Susu, Ikan, Daging dan Telur. Yogyakarta : Liberty.

Handayani, T. 2013. Khasiat Ampuh Akar Batang Daun Musnahkan Segala Penyakit. Lampung : Infra Pustaka.

Harris, A. 2011. Pengaruh Substitusi Ubi Jalar (Ipomea batatas) dengan Susu Skim Terhadap Pembuatan Es Krim. Skripsi. Makassar : Fakultas Pertanian Universitas Hasanuddin.

Hartanto, A. 2011. Pengaruh Konsentrasi Gula Pasir, Asam Sitrat dan Tingkat Pemanasan Pada Gula Invert dalam Manisan Rosella Kering (Hibicus sabdariffa) Ditinjau Dari Sifat Fisikokimia dan Sensori. Skripsi. Universitas Katolik Soegijapranata Semarang.

Hubeis, M. 1995. Paket Industri Pangan Es Krim Ekonomi Skala Kecil. Bulletin Fakultas Teknologi Industri Pangan. Institut Pertanian Bogor. Vol. VII (I) hal. 100-102.

Ismunandar. 2004. Dibalik Lembutnya Es Krim. Departemen Kimia FMIPA ITB. http://www.kimianet.lipi/go.id (Diakses tgl 25 April 2020).

Jannah, V. 2013. Suplemen Herbal Kaya Nutrisi Berbasis Daun Kelor Sebagai Alternatif makanan Olahan dalam Rangka Peningkatan Kualitas Hidup Penderita HIV/AIDS di Kelompok Dukungan Sebaya (DKS) Cita Cilacap. Laporan PKM-M. Cilacap : Stikes Al Irsyad Al Islamiyyah Cilacap.

Jonni, M.S., Sitorus, M. dan Katharina, N. 2008. Cegah Malnutrisi dengan Kelor. Yogyakarta : Penerbit Kanisius.

Kalsum, Umi. 2012. Kualitas Organoleptik dan Kecepatan Meleleh Es Krim dengan Penambahan Tepung Porang (Amorphopallus onchopillus) sebagai Bahan Penstabil. Makassar : Universitas Hasanuddin.

Khomsan, A. 2004. Pangan Dan Gizi Untuk Kesehatan. Jakarta : PT. Raja Grafindo Persada.

Kurnianingsih, S. R. 2015. Pengaruh Penambahan Tepung Daun Kelor (Moringa oleiferaa L.) Pada Karakteristik Fisikokimia dan Sensoris Es Krim. Skripsi. Semarang : Program Studi Teknologi Pangan Fakultas Teknologi Pertanian Universitas Katolik Soegijapranata.

Marshall, R.T., Arbuckle, W.S. 1996. Ice Cream 5th Edition. Champman and Hall, New York.

Nuraini, H. 2007. Memilih \& Membuat Jajanan Anak yang Sehat. Surabaya : Trubus Agrisarana, Nutritions Facts Susu Diamond Full Cream, 2020.

Oksilia, M. I. Syafutri, dan E. Lidasari. 2012. Karakteristik Es Krim Hasil Modifikasi Dengan Formulasi Bubur Timun Suri (Cucucmid melo L.) dan Sari Kedele. Jurnal Teknologi dan Industri Pangan. 23(1):17-22.

Padaga, M dan M, E, Sawitri. 2005. Es Krim Yang Sehat. Trubus Agrisana : Surabaya.

Panjaitan, T. S. 2013. Kelor Mineral Blok Suplemen. Litbang Pertanian 